\title{
Mycorrhization of Pinus halepensis Mill. and Pinus pinaster Aiton seedlings in two commercial nurseries
}

\author{
Ana Isabel González-Ochoa ${ }^{\mathrm{a} *}$, Jorge de las Heras ${ }^{\mathrm{a}}$, Pilar Torres ${ }^{\mathrm{b}}$ and Elena Sánchez-Gómez ${ }^{\mathrm{a}}$ \\ ${ }^{a}$ Departamento de Producción Vegetal y Tecnología Agraria, Universidad de Castilla-La Mancha, Campus Universitario s/n 02071, Albacete, Spain \\ ${ }^{\mathrm{b}}$ Departamento de Biología Aplicada, Universidad de Miguel Hernández, Carretera Beniel km 3.2, Orihuela, Spain
}

(Received 12 July 2001; accepted 24 January 2002)

\begin{abstract}
Two Mediterranean pine species (Pinus halepensis and Pinus pinaster) and seven fungi species (Pisolithus tinctorius, Lactarius deliciosus, L. sanguifluus, Suillus mediterranensis, S. collinitus, S. bellinii, and Rhizopogon roseolus) were selected for a mycorrhization study in two nurseries of SE Spain. Two types of inoculum (spore suspension and mycelium inoculum) were used on 3700 pine seedlings. The aim of the study was to ascertain the influence of two different substrata (composted pine bark and fertilized-peat-vermiculite) on the mycorrhization rate and pine seedlings height. The results pointed out significantly differences between both substrata. In general, the best results were obtained with fertilized-peat-vermiculite-substratum although both the mycorrhization rate and seedlings height varied according to fungi species and the inoculum type used.
\end{abstract}

Pinus halepensis / Pinus pinaster / substrata / mycorrhization

Résumé - Mycorhization de semis de Pinus halepensis Mill. et Pinus pinaster Aiton dans deux pépinières forestières. Deux espèces méditerranéennes de pin (Pinus halepensis et Pinus pinaster) et sept espèces de champignons (Pisolithus tinctorius, Lactarius deliciosus, L. sanguifluus, Suillus mediterranensis, S. collinitus, S. bellinii et Rhizopogon roseolus) ont été choisis pour une étude de mycorhization dans deux pépinières du Sud-est de l'Espagne. Deux types d'inoculum (suspension de spores et inoculum de mycélium) ont été employés sur 3700 semis de pin. Le but de ce travail est d'étudier l'influence de deux substrats différents (écorce de pin compostée et tourbe-vermiculite fertilisée) sur le taux de mycorhization et la hauteur de semis de pin. Les résultats ont montré des différences significatives entre les deux substrats. En général, les meilleurs résultats ont été obtenus pour le substrat tourbe-vermiculite fertilisée, mais le taux de mycorhization et la hauteur de jeunes plants dépendait de l'espèce de champignon et du type d'inoculum.

Pinus halpensis / Pinus pinaster / substrat / mycorhization

\section{INTRODUCTION}

During the last decades, the application of mycorrhizas in forestry has experienced a very important growth. Noteworthy studies are related to the selection of those fungi species and isolates which best adapt to the environmental conditions [4, $21,29]$, the most effective inoculum production techniques [6, $14,21,22,24,26-28]$, and the inoculation and production of forestry species in the nursery $[1,2,19]$. These studies and many others have contributed to a considerable increase in profitability of the forest plant production $[6,19]$ and also the use of mycorrhized plants for afforestations purposes [7, 23].

Several studies have been carried out to facilitate the largescale application and development of mycorrhization techniques. Initially, the spore inoculum method was the most widely used [17], while several authors tested the viability of mycelium inoculum at an industrial level [24, 25]. More recently, several new production methods for large quantities of mycelium have been developed including liquid fermentation using bio-reactors, and solid fermentation in vermiculite medium [9, 12].

In several Mediterranean countries and primarily in Spain, many studies have been carried out on two pine species, Pinus halepensis $[8,18]$ and Pinus pinaster. Some of these studies are based on morphological descriptions of mycorrhizas obtained under natural conditions $[11,13]$. Other authors studied the utility of mature forest soil samples as an inoculum source [16]. As regards the studies involving controlled mycorrhization, those in which mycorrhizas were obtained under axenic conditions or even produced in vitro are of note. Furthermore, the formation of mycorrhizas between Pinus halepensis and Amanita spissa, Lactarius deliciosus, Hebeloma edurum, Suillus luteus and Suillus variegates was described [38]. Besides, spore inoculum has been successfully tested with Pinus halepensis and Suillus collinitus, Rhizopogon roseolus and Pisolithus tinctorius in containers [39]. Several mycelial inocula have 
also been studied using Thelephora terrestris, Suillus collinitus, S. mediterranensis, Rhizopogon sp. and Pisolithus tinctorius $[6,16,34]$. As regards Pinus pinaster, most studies have been carried out in Northern Spain, using Pisolithus tinctorius, Rhizopogon sp. and Laccaria bicolour as fungal species [29].

However, few papers written in Spanish consider the effects of nursery conditions on mycorrhization. In this sense, [16] studied the relation between several substrata and mycorrhization rates in various nurseries, obtaining significant differences in the process.

The purpose of this study was to ascertain the effects of two different substrata (composted pine bark and fertilized peatvermiculite) on the mycorrhization rate and seedlings growth in the two most commonly used pines Pinus halepensis and Pinus pinaster, in two forestry nurseries of the Albacete province (SE Spain), using seven fungal species (Pisolithus tinctorius, Lactarius deliciosus, L. sanguifluus, Suillus mediterranensis, S. collinitus, S. bellinii and Rhizopogon roseolus). The main objective was to improve tree growth in the nurseries.

\section{MATERIALS AND METHODS}

Thermoformed plastic containers $(220 \mathrm{~mL}$ capacity) were used after disinfections in water and bleach (1:1), before being filled with 2 types of substrate, one for each nursery: Dermont II substratum (composed bark pine), $\mathrm{pH}=5.5$, and sterilized using thermal shock at $600{ }^{\circ} \mathrm{C}$ in nursery A. A mixture of solid fertilized peat-vermiculite(75\%-24\%) substratum, $\mathrm{pH}=5.7$ (after sterilization) and sterilized 3 times at $100{ }^{\circ} \mathrm{C}$ dry for $1 \mathrm{~h}$ once a week for 3 weeks in the nursery B.

Pinus halepensis and $P$. pinaster seeds were obtained from the Alcaraz-Segura mountain Range, located in SW Albacete province (SE Spain). No prior scarification or stratification treatments were applied. The seeds were rinsed in tap water and surface-sterilized with $\mathrm{H}_{2} \mathrm{O}_{2}(30 \%)$ for 20 min. After sterilization, the seeds were sown in the containers in March 2000 (3 seeds/cavity). Germination occurred 15-20 days after sowing and seedlings were thinned to one seedling per cavity.

Fruit bodies of all the fungi species ( $S$. bellinii, S. collinitus, $S$. mediterraneensis, L. deliciosus, L. sanguifluus, $R$. roseolus and $P$. tinctorius) were collected in the Alcaraz-Segura Range in AutumnWinter 1999. Isolates were obtained from the fruit bodies and some of them were preserved to obtain spore suspension.

\section{Experimental design}

Two types of inoculum were obtained: spore suspension and mycelium inoculum. Culture media were MMN for Suillus and Rhizopogon species and BAF for Lactarius species [37]. In all cases, mycelia were grown in 1-litre bottles with liquid medium previously sterilized and incubated at $23{ }^{\circ} \mathrm{C}$ for 3 months. Spore suspensions were made using techniques described by [3]. This method consists of preparing spore slurries from fragments of hymenium, which are then triturated in sterile distilled water. Suspensions were frozen at $-15^{\circ} \mathrm{C}$ until inoculation. In relation to the number of basidiospores per seedling used, [39] noted that $10^{4}-10^{7}$ spores/seedling are sufficient to guarantee mycorrhization. In this study, $1.5 \times 10^{9}$ spores/seedling were used for $P$. tinctorius, $1.3 \times 10^{5}$ spores/seedling for $R$. roseolus, $1.4 \times$ $10^{4}$ spores/seedling for Suillus species and $0.7 \times 10^{5}$ spores/seedling for Lactarius species.

In June 2000, 1260 seedlings (630 of $P$. halepensis and 630 of $P$. pinaster) were inoculated in nursery A, and 1440 seedlings $(720$ from $P$. halepensis and 720 from $P$. pinaster) in nursery B. In all cases, $10 \mathrm{~mL} / \mathrm{seedling}$ of mycelium inocula were applied on Lactarius, Rhizopogon and Suillus species. Inoculation was performed by injection of liquid inoculum using a micropipette. Three different containers (replicates) were used in each treatment. At the same time, the above mentioned dose of spore inoculum was used in the following combinations: $P$. halepensis $\times S$. collinitus, $P$. halepensis $\times S$. mediterranensis, $P$. halepensis $\times$ L. deliciosus, $P$. halepensis $\times P$ tinctorius, $P$. pinaster $\times L$. deliciosus, $P$. pinaster $\times P$. tinctorius. Seedlings growth was evaluated six months after inoculation by measuring total height. Mycorrhization was evaluated considering the total number of inoculated seedlings of $P$. halepensis and $P$. pinaster. For this, each seedling was studied separately. The parameters used for quantitative estimation were: (1) Mycorrhization rate, relation between number of mycorrhized and the total number of seedlings for each pine-inoculum combination. (2) Percentage of ectomycorrhizas observed in each root system for each pine-inoculum combination. These values were grouped into six classes in accordance with [17]. 0 (0\% mycorrhization); 1 (1-20\%); 2 (21-40\%); $3(41-60 \%) ; 4(61-80 \%)$ and $5(81-100 \%)$. (3) Infection index, the average value obtained using the above classes for each treatment. Culture conditions were similar in nurseries A and B. In both of them plants were watered daily by using minidiffusers. All containers were cultured under shading condition. Besides, the culture parameters in both nurseries were similar: no weed-killer, fungi-killer nor fertilizers were applied. In addition, the same kind of thermoformed plastic container was used.

All data were subjected to analysis of variance and significant differences were determined using the Duncan's test $(P<0.05)$. In addition, simple regression models were calculated for height-percentage of ecomycorrhiza for those treatments in which average ectomycorrhizas exceeded $50 \%$. Data shown as percentages were transformed using arcsin transformation to meet the assumptions of normality and homocedascity.

\section{RESULTS}

Tables $I$ and $I I$ show a quantitative and qualitative evaluation of ectomycorrhizas obtained from all the seedlings in each treatment (an average of 105 seedlings per treatment due to seedlings death). In tables $I$ and $I I$ infection index mean are noted. For all the fungal treatments more than one fungal species appears in $P$. halepensis as well as in $P$. pinaster. Apart from the inoculated species, different contaminant fungi were detected, mainly $P$. tinctorius and particularly Thelephora terrestris.

Class 1 (1-20\% mycorrhization) was the most frequent class for both $P$. halepensis and $P$. pinaster $(0$ means no mycorrhization) followed by class $2(20-40 \%)$. On the other hand, mycorrhization percentages were higher in nursery $\mathrm{B}$ than in $\mathrm{A}$.

For $P$. halepensis in nursery $\mathrm{A}$, the highest mycorrhization percentage (70-80\%) referred to $T$. terrestris. In nursery B, $T$. terrestris also appeared but with lower mycorrhization percentages than in the nursery A.

In the case of $P$. pinaster the mycorrhization percentages of $T$. terrestris were higher than those obtained for $P$. halepensis in both nurseries, ranging from 80 to $100 \%$.

\subsection{Pinus halepensis mycorrhization percentage}

From all the fungal species tested in nursery A, spore inoculum of Suillus and Lactarius showed the highest mycorrhization 
Table I. Infection index and height of 6-month-old P. halepensis seedlings in 2 substrates inoculated with different fungi treatments. In each column, treatments with different letters have significant differences $(P<0.05)$. Sb: Suillus bellini; Sc: Suillus collinitus; Sm: Suillus mediterranensis; Ld: Lactarius deliciosus; Ls: Lactarius sangluifluus; Pt: Pisolithus tinctorius; Rr: Rhizopogon roseolus; m: mycelium; s: spore.

\begin{tabular}{ccccc}
\hline Fungi & \multicolumn{2}{c}{ Infection index } & \multicolumn{2}{c}{ Height $(\mathrm{cm})$} \\
\cline { 2 - 5 } Treatment & Nursery A & Nursery B & Nursery A & Nursery B \\
\hline Control & - & - & $17.0^{\mathrm{c}}$ & $8.1^{\mathrm{cd}}$ \\
$\mathrm{Sb} \mathrm{m}$ & $1.0^{\mathrm{a}}$ & - & $19.5^{\mathrm{e}}$ & $8.8^{\mathrm{e}}$ \\
$\mathrm{Sc} \mathrm{m}$ & $1.0^{\mathrm{a}}$ & $1.0^{\mathrm{a}}$ & $18.5^{\mathrm{cde}}$ & $8.9^{\mathrm{e}}$ \\
$\mathrm{Sc} \mathrm{s}$ & $1.3^{\mathrm{b}}$ & $1.3^{\mathrm{a}}$ & $15.4^{\mathrm{a}}$ & $7.4^{\mathrm{b}}$ \\
$\mathrm{Sm} \mathrm{m}$ & $1.4^{\mathrm{b}}$ & - & $18.1^{\mathrm{c}}$ & $9.4^{\mathrm{f}}$ \\
$\mathrm{Sm} \mathrm{s}$ & $1.0^{\mathrm{a}}$ & $1.0^{\mathrm{a}}$ & $15.0^{\mathrm{a}}$ & $7.6^{\mathrm{bc}}$ \\
$\mathrm{Ld} \mathrm{s}$ & $1.1^{\mathrm{a}}$ & $1.0^{\mathrm{a}}$ & $18.5^{\mathrm{cde}}$ & $8.8^{\mathrm{e}}$ \\
$\mathrm{Ld} \mathrm{m}$ & $1.0^{\mathrm{a}}$ & $1.0^{\mathrm{a}}$ & $18.4^{\mathrm{cd}}$ & $8.5^{\mathrm{de}}$ \\
$\mathrm{Ls} \mathrm{m}$ & $1.0^{\mathrm{a}}$ & $1.0^{\mathrm{a}}$ & $19.1^{\mathrm{de}}$ & $8.5^{\mathrm{de}}$ \\
$\mathrm{Pt} \mathrm{s}$ & $1.0^{\mathrm{a}}$ & - & $18.5^{\mathrm{cd}}$ & $7.8^{\mathrm{bc}}$ \\
$\mathrm{Rr} \mathrm{m}$ & - & $1.1^{\mathrm{a}}$ & $18.3^{\mathrm{cd}}$ & $5.2^{\mathrm{a}}$ \\
\hline
\end{tabular}

percentages (ranging from 40-65\%). The same fungal species but with mycelium inoculum showed lower values (between $18-30 \%)$.

The best inoculations recorded in nursery B were obtained with the L. sanguifluus mycelial inoculum (64\%) and with L. deliciosus spore inoculum (55\%). For the remaining fungal species, the percentages of mycorrhized plants were lower or null.

\subsection{Pinus pinaster mycorrhization percentage}

The fungal treatments leading to the highest mycorrhization percentages were those with mycelium and spore inoculum of Lactarius in nursery A. Spore inoculum was the best with $93 \%$ of the seedlings micorrhized. In nursery $\mathrm{B}, R$. roseolus showed a mycorrhization percentage of $80 \%$ with no other colonization species appearing in the trays treated with this mycelium species. On the contrary, $R$. roseolus in nursery A did not show a high mycorrhization percentage $(24.8 \%)$ and it was infected by $T$. terrestris.

In nursery B the spore inoculum of $S$. mediterranensis showed $64 \%$ mycorrhization percentage, whereas this treatment in nursery A yielded only $7 \%$.

Dealing with infection index and medium height $(\mathrm{cm})$ of the seedlings (tables $I$ and $I I$ ), for $P$. halepensis in nursery $\mathrm{B}$ two homogeneous groups appeared, one including $S$. mediterranensis mycelial inoculum (with the highest infection index) and the second group with the remaining treatments. For this species only one group appeared in nursery B. For $P$. pinaster four different homogeneous groups appeared in nursery A, while three groups appeared in nursery B. In nursery A, L. deliciosus mycelium showed the highest infection index (1.9), while in nursery B, $R$. roseolus mycelium gave the highest colonization rate (1.3).

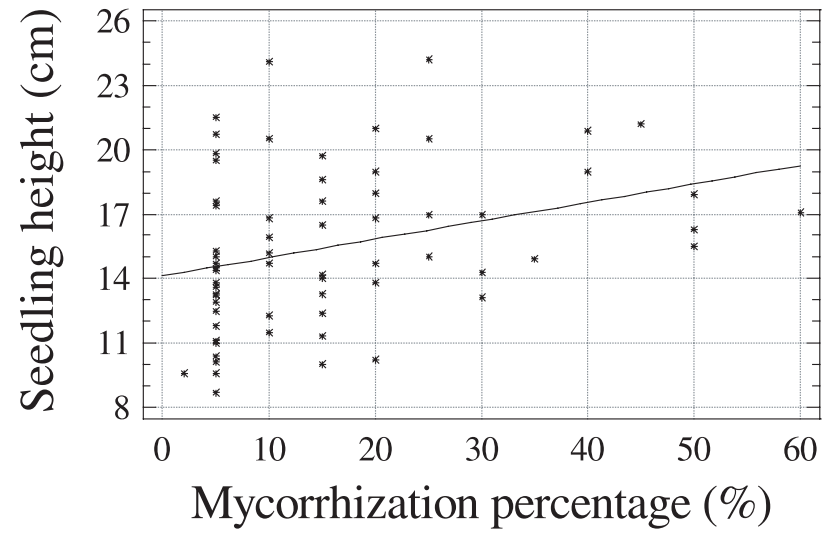

Figure 1. Regression model for $P$. halepensis seedlings inoculated with $S$. collinitus in nursery A. $\mathrm{Y}=0.085656 \mathrm{x}+14.1214 ; \mathrm{r}=0.32$; $\mathrm{R}^{2}=10.26 \% ; P<0.05$.

Table II. Infection index and height of 6-month-old $P$. pinaster seedlings in 2 substrates. In each column, treatments with different letters have significant differences $(P<0.05)$. Sb: Suillus bellini; Sc: Suillus collinitus; Sm: Suillus mediterranensis; Ld: Lactarius deliciosus; Ls: Lactarius sangluifluus; Pt: Pisolithus tinctorius; Rr: Rhizopogon roseolus; m: mycelium; s: spore.

\begin{tabular}{ccccc}
\hline Fungi & \multicolumn{2}{c}{ Infection index } & \multicolumn{2}{c}{ Height $(\mathrm{cm})$} \\
\cline { 2 - 5 } Treatment & Nursery A & Nursery B & Nursery A & Nursery B \\
\hline Control & - & - & $19.4^{\mathrm{abc}}$ & $9.0^{\mathrm{ed}}$ \\
$\mathrm{Sb} \mathrm{m}$ & $1.4^{\mathrm{bc}}$ & $1.0^{\mathrm{ab}}$ & $18.1^{\mathrm{b}}$ & $9.9^{\mathrm{fg}}$ \\
$\mathrm{Sc} \mathrm{m}$ & $1.1^{\mathrm{a}}$ & $1.0^{\mathrm{abc}}$ & $22.0^{\mathrm{d}}$ & $10.4^{\mathrm{h}}$ \\
$\mathrm{Sc} \mathrm{s}$ & - & $1.0^{\mathrm{a}}$ & - & $8.4^{\mathrm{b}}$ \\
$\mathrm{Sm} \mathrm{m}$ & $1.0^{\mathrm{ab}}$ & $1.5^{\mathrm{c}}$ & $18.3^{\mathrm{b}}$ & $10.3^{\mathrm{gh}}$ \\
Sm s & - & $1.0^{\mathrm{a}}$ & - & $8.9^{\mathrm{cd}}$ \\
Ld s & $1.0^{\mathrm{a}}$ & $1.0^{\mathrm{a}}$ & $19.8^{\mathrm{c}}$ & $10.0^{\mathrm{gh}}$ \\
Ld m & $1.9^{\mathrm{d}}$ & $1.0^{\mathrm{a}}$ & $23.0^{\mathrm{e}}$ & $9.2^{\mathrm{de}}$ \\
Ls m & $1.1^{\mathrm{a}}$ & $1.0^{\mathrm{a}}$ & $19.3^{\mathrm{bc}}$ & $8.7^{\mathrm{bc}}$ \\
Pt s & $1.2^{\mathrm{abc}}$ & $1.0^{\mathrm{ab}}$ & $15.9^{\mathrm{a}}$ & $9.5^{\mathrm{ef}}$ \\
Rr m & $1.5^{\mathrm{b}}$ & $1.3^{\mathrm{bc}}$ & $18.4^{\mathrm{bc}}$ & $7.7^{\mathrm{a}}$ \\
\hline
\end{tabular}

In nursery A, 5 homogeneous groups appeared for seedling height. P. tinctorius showed the lowest value with $15.9 \mathrm{~cm}$, while L. deliciosus mycelium showed the highest with $23 \mathrm{~cm}$. In nursery B, 8 different groups were detected. $R$. roseolus mycelium was the fungal treatment producing the lowest seedling height $(7.7 \mathrm{~cm})$ while $S$. collinitus produced the highest with a value of $10.4 \mathrm{~cm}$. Seedling height was always higher in nursery A than in nursery B for all treatments tested.

Regression analysis between height and mycorrhization percentage of inoculated fungi was significant $(P<0.05)$ for spore inoculum treatments of $S$. collinitus with $P$. halepensis in nursery A (figure 1) and for spore inoculum of $S$. mediterranensis with $P$. pinaster in nursery B (figure 2 ). 


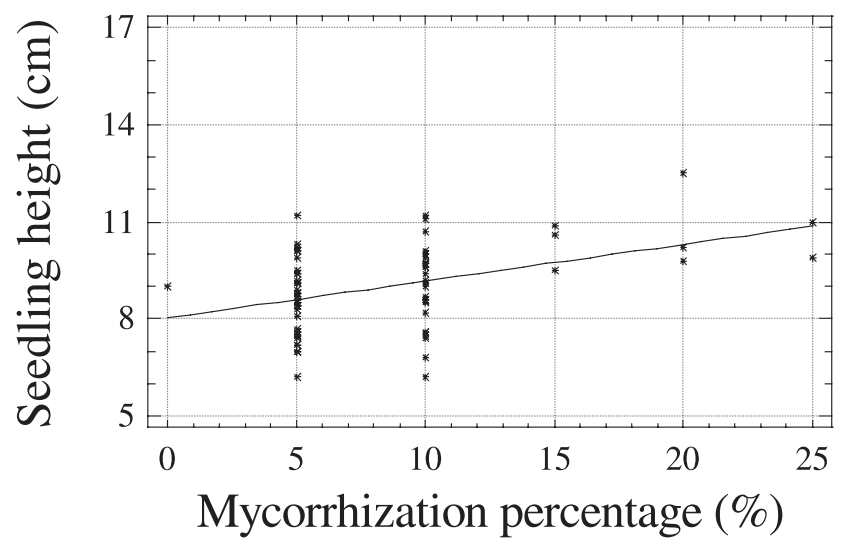

Figure 2. Regression model for $P$. pinaster seedlings inoculated with $S$. mediterranensis in nursery B. $\mathrm{Y}=0.113282 \mathrm{x}+8.03933$; $\mathrm{r}=0.42 ; \mathrm{R}^{2}=18.09 \% ; P<0.05$.

Table III. Mycorrhization percentage (\%) for $P$. halepensis treatments in both nurseries. In each row, values with different letters show significant differences $(P<0.05)$.

\begin{tabular}{ccc}
\hline P. halepensis & Nursery A & Nursery B \\
\hline Ld s & $11.09 \pm 7.62^{\mathrm{a}}$ & $10.88 \pm 5.59^{\mathrm{a}}$ \\
Sm s & $17.97 \pm 14.8^{\mathrm{a}}$ & $10.38 \pm 7.7^{\mathrm{a}}$ \\
Ld m & $7.01 \pm 5.08^{\mathrm{a}}$ & $8.65 \pm 9.01^{\mathrm{a}}$ \\
\hline
\end{tabular}

In the case of spore inoculum of $S$. collinitus, the $\mathrm{R}^{2}$ value obtained means that the adjusted model explains $10.26 \%$ of the height variability. The correlation coefficient was 0.32 . For $S$. mediterranensis and $P$. pinaster the mycorrhization percentage explained $18.09 \%$ of height variability. The correlation coefficient was 0.42 . The positive slope in both regression models means that the higher the percentage of mycorrhization, the taller the saplings.

Comparisons between the same treatment and between the two nurseries were also done (tables III and $V I$ ). For this purpose only those treatments whose mycorrhization rate was higher than $10 \%$ were considered.

For $P$. halepensis, no significant differences appeared between the two kinds of substrate (both nurseries) in the case of $L$. deliciosus spore, S. mediterranensis spore and L. deliciosus mycelium (table III).

For P. pinaster (table IV), L. deliciosus spore was the only treatment where significant differences were recorded between the two nurseries $(30.25 \pm 17.7$ in nursery $\mathrm{A}$ and $7.03 \pm 2.99$ in nursery B). No significant differences appeared between the remaining tested treatments ( $L$. deliciosus mycelium, $L$. sanguifluus mycelium and $R$. roseolus mycelium).

For P. halepensis (table V), the L. deliciosus spore mycorrhization percentage was significantly higher than the observed for the L. deliciosus mycelium inoculum in nursery A. On the contrary, in nursery B there were not significant differences. S. collinitus spore showed a $16.23 \pm 13.75$ mycorrhization percentage while $S$. collinitus mycelium showed
Table IV. Mycorrhization percentage (\%) for $P$. pinaster treatments in both nurseries. In each row, values with different letters show significant differences $(P<0.05)$.

\begin{tabular}{ccr}
\hline P. pinaster & Nursery A & \multicolumn{1}{c}{ Nursery B } \\
\hline Ld s & $30.25 \pm 17.7^{\mathrm{a}}$ & $7.03 \pm 2.99^{\mathrm{b}}$ \\
Ld m & $10.21 \pm 5.07^{\mathrm{a}}$ & $8.0 \pm 3.68^{\mathrm{a}}$ \\
Ls m & $9.35 \pm 6.04^{\mathrm{a}}$ & $8.65 \pm 4.01^{\mathrm{a}}$ \\
Rr m & $14.83 \pm 9.20^{\mathrm{a}}$ & $15.45 \pm 7.43^{\mathrm{a}}$ \\
\hline
\end{tabular}

Table V. Mycorrhization percentage (\%) for P. halepensis treatments in both spore and mycelium inoculum. In each row, values with different letters show significant differences $(P<0.05)$.

\begin{tabular}{ccc}
\hline$P$. halepensis & Spore inoculum & Mycelium inoculum \\
\hline Ld Ph nursery A & $11.09 \pm 7.62^{\mathrm{a}}$ & $7.01 \pm 5.08^{\mathrm{b}}$ \\
Sc Ph nursery A & $16.23 \pm 13.75^{\mathrm{a}}$ & $9.55 \pm 1.6^{\mathrm{b}}$ \\
Ld Ph nursery B & $18.88 \pm 5.59^{\mathrm{a}}$ & $8.65 \pm 9.01^{\mathrm{a}}$ \\
\hline
\end{tabular}

Table VI. Mycorrhization percentage (\%) for $P$. pinaster treatments in both spore and mycelium inoculum. In each row, values with different letters show significant differences $(P<0.05)$.

\begin{tabular}{ccc}
\hline P. pinaster & Spore inoculum & Mycelium inoculum \\
\hline Ld Pp nursery A & $30.25 \pm 17.7^{\mathrm{a}}$ & $7.05 \pm 2.99^{\mathrm{b}}$ \\
Ld Pp nursery B & $10.21 \pm 5.07^{\mathrm{a}}$ & $8.0 \pm 3.68^{\mathrm{a}}$
\end{tabular}

a value of $9.55 \pm 1.6 \%$, which meant there were significant differences between them.

For $P$. pinaster (table VI), there was a significant difference between the mycorrhization percentage obtained with $L$. deliciosus spore and mycelial inoculum in nursery A (30.25 \pm 17.7 and $7.03 \pm 2.99$ respectively) while for the same treatments no significant differences appeared in nursery B $(10.21 \pm 5.07$ and $8.0 \pm 3.68)$

\section{DISCUSSION}

Mycorrhization percentage results reveal the susceptibility for $P$. halepensis and $P$. pinaster to be colonized by mycorrhizas. This fact has been demonstrated by other authors, who described the mycorrhizal colonization process with this species using similar techniques $[3,15,32,37,40]$. However, the different mycorrhization rates and the different mycorrhization percentages emphasize the importance of the fungal species selected [41], the inoculation techniques [36] and the most useful substrate which can be used for each pine species.

Substrate showed as the principal factor influencing on mycorrhyzation results. Whatever substrate is used, it should present sufficient ventilation and drainage to allow the development of the fungi mycelium [16]. Such characteristics are also necessary for the correct development of the seedlings. The $\mathrm{pH}$ of substrate used in nursery B (4.5-5.5) was lower than that in nursery A (5.5-5.9) which could mean that a 
moderately acid $\mathrm{pH}$ is better for ectomycorrhizal development. On the other hand, the fact that Lactarius is a genus only slightly affected by variations in $\mathrm{pH}$ [10] could explain the results obtained for that genus in nursery $\mathrm{B}$, where the mycorrhization percentages obtained were higher than those in nursery A.

The better results obtained for mycorrhizal colonization in nursery A could be due to the greater ability of the peatvermiculite mixture to encourage ectomycorrhizal development than the substrate of tritured bark pine. This could agree with the findings of other authors who demonstrated the compatibility of mixtures containing peat with the development of the ectomycorrhiza [3, 6].

The fungal treatments involving Suillus and Lactarius genus were in general successful both with mycelial and spore inoculum. Since spore inoculum is easily applied, this may be the most suitable method for inoculating seedlings in commercial nurseries, as demonstrated in other nurseries of SE Spain [17].

Comparing the results obtained for $P$. halepensis and $P$. pinaster, the former was found to be more receptive to colonization by ectomycorrhizal fungi than $P$. pinaster in both nurseries. This could be explained by the low number of seeds in $P$. halepensis, which needs to develop fine roots quickly, thus reducing the optimal time span for mycorrhization [10]. $P$. pinaster has larger seed stocks, and so, the time interval for inoculating the seedlings is longer.

T. terrestris is the other fungal species which appears in both nurseries in the majority of containers, demonstrating the natural adaptation of this species to the nursery conditions. This species is an important competitor in the development of other fungal species [39] which could explain the low mycorrhization rates and mycorrhization percentages obtained.

The significant differences in mean seedling height obtained for the different inocula is related to the presence of mycorrhiza. A significant relationship was observed for $S$. collinitus in P. halepensis in nursery A and for S. mediterranensis in $P$. pinaster in nursery B. However, the above correlations were not very high and indeed, other studies have concluded that the presence of ectomycorrhizas does not favour the growth of seedlings in containers. In such a situation, many processes which influence seedlings growth and which are due to the presence of mycorrhiza simply do not occur [31]. It is only later, when the seedling has been planted in the countryside, that the mycorrhiza has an effect on the survival and development of the seedlings [5, 25]. In some cases a negative influence of the mycorrhiza on height has been detected [35].

It is well known that the inclusion of a mycorrhization step in plant production has positive effects on the survival of seedlings when they are planted out [20, 30, 33]. However, the incorporation of a mycorrhization step in seedling productions in nurseries is not a common practice in Spain. This could be explained by the final economic value of the sapling, which although considerably higher than that of a non-mycorrhized plant, is not sufficient to recover any initial investment in the process. Besides, each nursery has its own particular production technique as shown in this study. As a consequence, the development of individual studies similar to this one is necessary for each nursery. The principal aim would be to identify the most effective inoculum technique from an economic and a biological point of view.

We can conclude that the effect of controlled inoculation in nurseries varies depending on the fungus species-seedling species combination, the substratum and production technique used. Despite this variation, a controlled mycorrhization process is always possible.

Acknowledgements: This work has been supported by the research project from the FEDER Programme (1FD97-0441). We would like to thank to Kathy Walsh for her assistance in reviewing the English version of the manuscript and to Eugenia Simarro for her help in field work.

\section{REFERENCES}

[1] Browing M.H.R., Withney R.D., Responses of jack pine and black spruce seedlings to inoculation with selected species of ectomycorrhizal fungi, Can. J. Res. 21 (1991) 701-706.

[2] Calamassi R., Della Roca G., Falusi M., Paoletti E., Strati S., Resistances to water stress in seedlings of eight European provenances of Pinus halepensis Mill., Ann. For. Sci. 58 (2001) 663-672.

[3] Carrillo C., Producción de inóculo de hongos ectomicorrícicos y micorrización controlada de Pinus halepensis Miller en vivero, Tesis doctoral. Universidad de Murcia, 2000, $241 \mathrm{p}$.

[4] Castellano M.A., Molina R., Mycorrhizae, in: Landis T.D., Tinus R.W., McDonald S.E., Barnet J.P. (Eds.), The container nursery manual, Vol. 5, Agric Handbook 674, Washington D.C., USDA Forest Service, 1989, pp. 102-107.

[5] Castellano M.A., Outplanting performance of mycorrhizal inoculated seedlings: a review, in: Proceedings of the Eighth North American Conference on Mycorrhizae, 1990, p. 49.

[6] Cordell C.E., Marx D.H., Maul S.B., Owen J.H., Production and utilization of ectomycorrhizal fungal inoculum in the eastern United States, in: Sylvia D.M., Hung L.L., Graham J.H. (Eds.), Mycorrhizae in the next decade. Practical applications and research priorities, Proceedings of the Seventh North American Conference on Mycorrhizae, University of Florida, Gainesville, 1987, pp. 287-289.

[7] Dixon R.K., Garret H.E., Cox G.S., Johnson P.S., Sanders I.L., Container and nursery-grown black oak seedlings inoculated with Pisolithus tinctorius growth and ectomycorrhizal development followings outplanting on Ozak clear-cut, Can. J. For. Res. 11 (1981) 492-496.

[8] Díaz G., Honrubia M., Factors affecting mycorrhizal infection of containerized Pinus halepensis by Suillus sp. and Pisolithus tinctorius in nursery conditions, Abstract Second International Conference on mycorrhiza, 1998, ICOM II 51.

[9] Durand A., The INRA-Dijon reactors: design and applications. Abstracts of IInd International symposium on Solid State Fermentation, Montpellier (France), 1995.

[10] Espigol R., Estado actual del cultivo de Lactarius deliciosus, in: Colinas C., Fischer C. (Eds.), Cultivo de hongos comestibles micorrícos, Publicaciones Universidad de Lleida, 1999, pp. 125-130.

[11] Fernández de Ana-Magán F., Rodríguez A., Os cogumelos nos ecosistemas forestais galegos, Xerais de Galicia, S.A., Vigo, 2000.

[12] Garbaye J., Utilisation des mycorhizes en sylviculture, in: Les mycorhizes des arbres et plantes cultivées, P.G. Strullu (Ed), Lavosier, Paris, 1991.

[13] García G., Caracterización y aspectos dinámicos del componente ectomicorrícico de los ecosistemas mediterráneos, Tesis doctoral, Universidad de Murcia, Murcia (España), 1998. 
[14] Guerin-Laguette A., Plassard C., Mousain D., Effects of experimental conditions on mycorrhizal relationships between Pinus sylvestris and Lactarius deliciosus and unprecedented fruitbody formation of the saffron milk cap under controlled suilless conditions, Can. J. Microbiol. 46 (2000) 790-799.

[15] Honrubia M., Carrillo C., Peñuelas J., Domínguez S., Villar P., Ocaña L., Influencia de la fertirrigación en la micorrización controlada de Pinus halepensis en vivero, Actas II Congreso Forestal Nacional, I Congreso Forestal Hispano-Luso, Irati (España), 1997a, pp. 307-311.

[16] Honrubia M., Díaz G., Gutiérrez A., Micorrización controlada de Pinus halepensis en vivero en función de la dosis de inóculo y técnicas de cultivo, Actas II Congreso Forestal Nacional, I Congreso Forestal Hispano-Luso, Irati (España), 1997b, pp. 301-306.

[17] Honrubia M., Torres P., Díaz G., Cano A., Manual para micorrizar plantas en viveros forestales, Proyecto LUCDEME VIII, Monografías 54, 1992.

[18] Honrubia M., Mycorrhizas in Pinus halepensis Miller, in: Ne'eman G., Trabaud L. (Eds.), Ecology biogeography and management of Pinus halepensis and $P$. brutia forest ecosystems in the Mediterranean basin, Backhuys Publ., 2000, pp. 191-202.

[19] Hung L.L., Trappe J.M., Ectomycorrhizal inoculation of Douglasfir transplanted container seedlings with commercially produced inoculum, New Forests 2 (1987) 141-152.

[20] Kropp B.R., Langlois C.G., Ectomycorrhizae in reforestation, Can. J. For. Res. 20 (1990) 438-451.

[21] Kuek C., Tommerup I.C., Malajczuk N., Hydrogel bead inocula for the production of ectomycorrhizal eucalypts for plantations, Mycol. Res. 96 (1992) 273-277.

[22] Le Tacon F., Efficacité en pépinière forestière d'un inoculum de champignon ectomycorhizien produit en fermenteur et inclus dans une matrice de polymères, Ann. Sci. For. 40 (1983) 165-176

[23] Le Tacon F., Garbaye J., Bouchard D., Chevailer G., Olivier J.M., Guimberteau J., Poitou N., Frochot H., Field results from ectomycorrhizal inoculation in France, in: Lalonde M., Piché Y. (Eds.), Proceedings of the Canadian Workshop on Mycorrhizae in Forestry, C.R.B.F., Faculté de Foresterie et de Géodésie, Université Laval, Sainte-Foy, Quebec (Canada), 1988.

[24] Marx D.H., Kenney D.S., Production of ectomycorrhizal inoculum in: Schenk N.C. (Ed.), Methods and principles of mycorrhizal research, Am. Phytophat. Soc., St. Paul, MN, 1982, pp. 131-146.

[25] Marx D.H., Ruehle J.L., Cordel C.E., Methods for studying nursery and field response of trees to specific ectomycorrhizae, in: Norris J.R., Read D.J., Varma A.K. (Eds.), Methods in microbiology, 23 , Tecniques for the study of mycorrhiza, Academic Press, London, 1991, pp. 384-411.

[26] Mauperin C., Mortier F., Garbaye J., Le Tacon F., Carr G., Viability of an ectomycorrhizal inoculum produced in a liquid medium and entrapped in a calcium alginate gel, Can. J. Bot. 65 (1987) 2326-2329.
[27] Molina R., Ectomycorrhizal inoculation of containerazied Douglas fir lodgeople seedlings with six isolated of Pisotithus tinctorius, For. Sci. 25 (1979) 585-590.

[28] Molina R., Palmer J.G., Isolation, maintenance and pure culture manipulation of ectomycorrhizal fungi, in: Schenk N.C. (Ed.), Methods and principles of mycorrhizal research, Am. Phytophat. Soc., St. Paul, MN, 1982, pp. 115-129.

[29] Mortier F., Le Tacon F., Garbaye J., Effect of inoculum type and inoculation dose on ectomycorrhizal development, root necrosis and growth of Douglas fir seedlings inoculated with Laccaria laccata in a nursery, Ann. Sci. For. 45 (1988) 301-310.

[30] Parladé J., Comportamiento en campo de planta de reforestación inoculada con hongos ectomicorrícicos, I Congreso sobre hongos en los ámbitos agrícola y forestal del SO de la Península Ibérica: Micorrización, Cáceres (España), 1999, pp. 61-73.

[31] Pera J., Selección de hongos ectomicorrícicos de Pinus pinaster Ait. Para su aplicación en reforestación. Tesis Doctoral, Univ. Autonoma de Barcelona., Barcelona, 1992.

[32] Pera J., Parladé J., Alvarez I.F., Eficacia del tipo de inóculo de Pisolithus tinctorius en la formación de micorrizas en Pinus pinaster y Pseudotsuga menziesii, Invest. Agrar., Sist. Recur. For. 3 (1994) 19-29.

[33] Querejeta J.I., Roldan A., Albadalejo J., Castillo V., The role of mycorrhizae, site preparation, and organic amendment in the afforestation of a semi-arid mediterranean site with Pinus halepensis, For. Sci. 44 (1998) 203-211.

[34] Ruehle J.L., Marx D.H., Bunnett J.P., Pawuk W.H., Survival and growth of container-grown and bare-root shortleaf pine seedlings with Pisolithus tinctorius and Thelephora terrestris ectomycorrhizas, South. J. Appl. For. 5 (1981) 20-25.

[35] Stenström E., Unesmat T., Survival and growth of container-grown and bare-root shortleaf pine seedlings with Pisolithus tinctorius and Thelephora terrestris ectomycorrhizas, South. J. Appl. 5 (1985) 20-24.

[36] Torres P., Estudio de las micorrizas de pino carrasco (Pinus halepensis Miller), Tesis Doctoral, Universidad de Murcia, Murcia, 1992.

[37] Torres P., Honrubia M., Morte A., In vitro synthesis of ectomycorrhizae between Suillus collinitus (Fr.) O. Kuntze, Rhizopogon roseolus (Corda) Th.M.Fr. with Pinus halepensis Miller, Mycotaxon 41 (1991) 437-445.

[38] Torres P., Honrubia M., Basidiospore viability in stored slurries, Mycol. Res. 98 (1994a) 527-530.

[39] Torres P., Honrubia M., Inoculation of containerized Pinus halepensis seedlings with basidiospores of Pisolithus tinctorius, Rhizopogon roseolus and Suillus collinitus, Ann. Sci. For. 51 (1994b) 521-528.

[40] Torres P., Honrubia M., Ectomycorrhizal associations proven for Pinus halepensis, Isr. J. Plant Sci. 42 (1994c) 51-58.

[41] Trappe J.M., Phylogenetic and ecology aspects of mycotrophy in the angiosperms from the evolutionary standpoint, in: Safir G.R. (Ed.), Ecophysiology of VA mycorrhizal plants, Press, Boca Raton, 